\title{
Guest editorial on transformation and societal change
}

\author{
Nicholas C. Georgantzas* \\ Fordham University Business Schools, NY, USA
}

\begin{abstract}
Catering to the growing community of scholars and practitioners who see the needed transformation and societal change in our modern temporality, this article serves as a preamble to a fascinating collection of five applied-research contributions. The article also defines our modernity's problematic mess, an attempt that creates the need to reconcile three hellenic '-isms', three philosophical constructs most pertinent to our modernity's quest for transformational and societal change. They are pertinent because all five research contributions this guest editorial is about rely on one or more of them either explicitly or implicitly. Newcomers to transformational and societal change research will find the brief overview of the requisite philosophical background useful as it emphasizes philosophy's value for future research. By integrating multiple, diverse perspectives, this Human Systems Management (HSM) Special Issue can serve as a prototype for future HSM special issues, which will further integrate transformation and societal change with research and practice in managing human, i.e., natural, systems and help identify new, exciting opportunities for future research in social science and beyond.
\end{abstract}

Keywords: Aristotle, democracy, dualism, economism, Heidegger, leverage, modernity, monism, parmenides, Plato, pluralism politics, society, systems, temporality, totalism

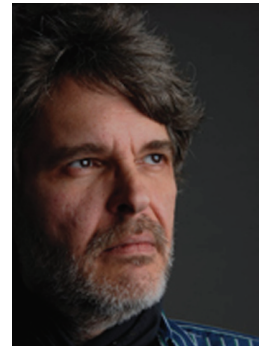

*Nicholas C. Georgantzas is Professor, Management Systems, and Director, System Dynamics (SD) Consultancy, Fordham University, New York, NY, USA. Both an Associate and a Guest Editor, System Dynamics Review, is also consultant to senior management as well as a forensic economist, specializing in SD simulation modeling for learning in strategy, production and business process (re) design. Author of ScenarioDriven Planning (Greenwood, 1995), has published expansively in refereed scholarly journals, conference proceedings and edited books. Mostly transdisciplinary, his research interests, publications and consulting entail systems thinking, knowledge technology and strategy design, focusing on the necessary theory and tools for learning in and about the dynamically complex systems in and about which we all live.

${ }^{*}$ Corresponding author: Nicholas C. Georgantzas, Fordham University Business Schools, 113 West 60th Street, Suite 617-D, New York, NY 10023-7484, USA. Tel.: +1 917667 4022; Fax: +1 212765 5573; E-mail: georgantzas@fordham.edu.

\section{Introduction}

To face calamity with a mind as unclouded as may be, and quickly to react against it - that, in a politeia and in a person, is real strength. — Thucydides

The eminently natural, dynamic movement of our cosmos scares phobic people. Its eternal kinesis makes the risk-averse deny its continuous metamorphosis, denouncing all that constitutes a supposedly frightening 'unknown'. Fear about what exactly that unknown is, incorporates the great fear of the loss of our ego, the ultimate fear, the fear of death. In order to eliminate fear, the word 'radical' is glaringly missing in front of the title of this HSM Special Issue. Yet, its contributors show that nothing short of radical transformation and societal change can reverse the downhill trends that all of us -phobic or not- see in the business, economic, educational, financial, societal and political systems of our modern temporality.

The data are in $[15,19,25]$. As they erupt from Tunisia to Tel Aviv to Wall Street, people's protests 
show that a societal metamorphosis is happening globally that needs defining. People cannot take it any more. Some say it is all part of The Big Shift: our system of financial crises, ineffective democracy and overloading planet Earth -our system- is eating itself alive. It is broken. Are we better off if we let it work, if we let the rich get richer fast at the expense of the rest of us, if we let corporations focus only on wealth accumulation, if we let pollution go unchecked? When the Occupy Wall Street (occupywallst.org) protests began, most news organizations were derisive if they deigned to mention the protests at all. What can we say about them? A useful critique of the protests is the absence of specific societal and political demands. Rich Yeselson, a veteran organizer and historian of societal movements, has suggested that debt relief for working Americans has become a central plank for the protests.

And perhaps infrastructure and technology investments -not just debt or tax cuts- can help create new jobs, a vexing research topic that Milan Zeleny's article deals with explicitly in this special issue. Meanwhile, in glorious Hellas and Italy, the governments of the bankers fell! That is the good news. The bad news is that, hereinafter, the bankers govern themselves. Back in the USA, taking Buffett's [5] cue, along with Rawls' [26] theoretical backing, President Obama proposed a 'millionaire tax' [6]. In an orwellian fashion, some Americans denounce it as a 'class war'. The truth is, however, that the super-rich have already won the war [31]. The incoming data could indeed be informing us of the beginning of a global revolution. But it is a knowledge revolution that this guest editorial advocates, as the entire HSM Special Issue does, for our modern temporality.

The following section defines our modernity's problematic mess, an attempt that creates the need to reconcile three hellenic '-isms', three philosophical constructs most pertinent to our modernity's quest for transformational and societal change. They are pertinent because all five research contributions this guest editorial is about rely on one or more of them either explicitly or implicitly. Newcomers to transformational and societal change research will find this brief overview of the requisite philosophical background useful as it emphasizes philosophy's value for future research. Next comes the brief overview of the fascinating collection of the five applied-research contributions in this HSM Special Issue. By integrating multiple, diverse perspectives, this special issue can serve as a prototype for future HSM special issues, which will further integrate transformation and societal change with research and practice in managing human, i.e., natural, systems and help identify new, exciting opportunities for future research in social science and beyond.

\section{Defining our modernity's problematic mess}

Hydrogen accumulation can cause the worst-case, 'China-syndrome' scenario to play in Fukushima, which, together with the Gulf of Mexico disaster makes a perfect example of the dire consequences of brutal cost cutting in our modern temporality. In their incisive prognosis of America's economic meltdown, Melissaratos and Slabbert [22] point a finger at decades of technological complacency and anti-scientific propaganda, which has left USA hostage to energy cartels, inept bailoutseekers, cripplingly obsolete technology and worthless financial paper. Their brilliant intellectual detective story, lucidly explains how artificial intelligence, biotechnology, energy research, global warming, the Internet, our knowledge economy, magnetic levitation, nanotechnology and physics dynamically intertwine and urgently relate to politics. In order to return America to the technology standard, so that it can build a magnificent civilization, with mass employment, environmental wisdom and energy sufficiency, Melissaratos and Slabbert conclude that science-challenged America must reclaim its hellenic roots.

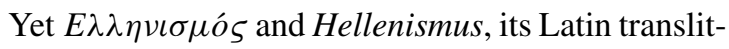
eration, do not exactly cover the same grounds. The former incorporates the idea of political leadership and the Aret $\overline{\mathrm{e}}$ or excellence it demands of citizens that serve us, the people. Its civic responsibility is

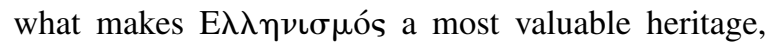
especially today, when the success of 'financialized technocratia' is changing the direction of democracy. The value of $o \mu o ́ v \iota \alpha$ or homonoia (concord) in public life as well as its task and responsibility, political in their essence, go beyond the narrow meaning of Hellenism as a humanistic field within the humanities. Its global responsibility renders the broader $\mathrm{E} \lambda \lambda \eta \nu \iota \sigma \mu$ ó a challenge, one that can hopefully lead to political and societal reforms for the benefit of all concerned. That is E $\lambda \lambda \eta \nu \iota \sigma \mu o ́ s$, waiting for us not only to be merely studied as a past, but as a living promise of the future [3].

Across the Atlantic, the European Union (EU) is not doing any better than Japan and USA are. "Contrary to the reported public debt of $€ 2$ trillion, the true German debt may well total $€ 7$ trillion as per calculations by Bernd Raffelhueschen, an economics professor at 
Freiburg University" [2]. In response, some EU countries have started looking back at EU's raison d'être:

I am convinced that in fifty years we will no longer think in terms of nations, but of continents, and that entirely different, and perhaps much larger, problems will concern Europe. Do not think that, as we bring about a certain order in Europe, we do it to harm individual nations. The freedom of individual countries must be brought in harmony with the conditions of the present and with simple questions of practicality. Just as a member of a family does not have the right to disturb everyone else's peace, an individual nation does not have the right to resist the larger order [30].

The fact that Paul Joseph Goebbels said that, while telling Czechs to get used to German occupation, must alarm most people, including those who's families lived and died in the Holocaust. And it might well be one of the motives behind Ackoff's quest for corporate democracy, an ideal neither painless for nations to practice nor any less painful for business corporations to embrace [1].

It is indeed fascinating to watch, in our modern temporality, the on-going Titanomachy between the principles behind Athenians' authentic democracy and those of the new 'financialized libertarian fascism' of sorts that The Group of Thirty (G30: www.group30.org) seems to be promoting. If the latter argument seems too strong, then one must look at a couple of historical examples that might help put some fresh meat around the shattered bones of the sinister, 'financialized zombie economism' skeleton that barely supports our postmodernity's economic and sociopolitical problematic situation.

Our problematic mess starts with the very problem that Aristotle posed, in what might be the very first major work of societal and political theory, his book on 'Politics'. Aristotle said that if wealth is highly con-

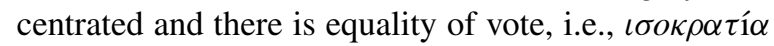
(isokratia), then the poor majority will use their voting power to carry out redistributive measures, i.e., an 'agrarian reform' in modernity, and that would be unfair. Aristotle's own solution to this problem was to try to reduce inequality, i.e., via 'societal-democratic' measures in modernity, and then enable democracy to flourish.

In the US constitutional convention debates [21], James Madison, a significant figure in our modernity's intellectual and political history, and the main framer of the US constitution, raised the same classic, societal and political theory problem, but he proposed exactly the opposite solution: reduce democracy and maintain inequality. So power, Madison claims, must be reserved to the wealth on the nation, i.e., the most capable set of men, i.e., land owners, who recognize that it is the government's responsibility to protect the opulent minority against the majority. The rest of us, the common people, must become marginalized and fragmented.

Closer to our time, the north America, Europe and Japan Trilateral Commission academics and intellectuals have been most concerned about the 'excess of democracy' since the $1960 \mathrm{~s}$. They urge 'moderation in democracy', to be implemented through the cooperation of a relatively small number of Wall Street bankers and lawyers. To reverse the excess of democracy, they deem necessary to overcome the failures of the institutions responsible for the indoctrination of the young, such as, for example, churches, schools and universities, which are not carrying out our 'proper' task of indoctrinating the young and thereby permit too many departures from orthodoxy and obedience. And that is a huge chunk of the problem that underlies the excess of democracy problematic, whenever the people try to enter the political arena where they do not belong (sic!).

As the $G 30$ force two former Prime Ministers, George Papandreou (Hellas) and Silvio Berlusconi (Italy) to exit the political palcoscenico (stage), with nothing but the idea of calming the markets in mind,

in the two battle-scarred capitals [Athens and Rome], the fact that Lucas Papademos and Mario Monti aren't directly accountable to the public isn't a problem. It's the reason they're being called in. Both countries have been tasked by the EU to attempt to restore confidence through deep cuts, sharp tax hikes and painful restructurings of the economy. The two technocrats have been tapped to lead because no politicians wants to face the electorate after doing what the markets have decreed needs to be done. "Democracy has very serious limitations" says Roberto D'Alimonte, a professor of political science at Rome's LUISS University. "It has the ability to kill itself, to self-destruct. [Bringing in a technocratic government] is not good or bad. It's necessary" [14].

In sharp contrast, just like Melissaratos and Slabbert [22], Ackoff too urges modern managers to aim for excellence or forever excelling, i.e., $\alpha 1 ́ \varepsilon v \alpha \rho \iota \sigma \tau \varepsilon v \varepsilon \varepsilon \nu$ (aien aristeuein), while they seek $\alpha \lambda \dot{\eta} \theta \varepsilon \iota \alpha$ (the truth), $\alpha \varphi \theta$ ovi $\alpha$ (the plenty), тo $\alpha \gamma \alpha \theta$ ó $v$ (the good) and $\alpha \iota \sigma \theta \eta \tau \iota \kappa \dot{\eta}$ (aesthetics) [1, pp. 49-50]. Yet to truly 
benefit from these four hellenic pillars, in their modern enterprise development, societal organizations must somehow first reconcile the three related hellenic notions of 'monism', 'dualism' and 'pluralism'.

\section{Reconciling three hellenic -isms}

In the context of reconciling monism, dualism and pluralism, Kaloy [18] calls $\sigma \tau \rho \circ \varphi \eta$, i.e., a bend, turn or twist, the internal process of the human intellect from oneness to multiplicity. And the process in opposition to 'strophe' is $\alpha \nu \tau \iota \sigma \tau \rho o \varphi \eta$, i.e., a turning back. It is possible to look at monism, dualism and pluralism as static notions, with a strife field among them (Fig. 1a). Through 'totalism', however, a theory that includes cognitive, aesthetic and moral components, Kaloy sees the potentiality of an 'antistrophe' in Plato, who refers all multiplicity to the idea of good; and to Descartes, who asserts that we would have no knowledge of the finite if we did not have a previous knowledge of the infinite. In the hellenic worldview, the entire deity multiplicity is subdued to the will of Zeus, i.e., the One. Likewise, the notion of Brahma in Indian tradition, with its 'this' with 'that' (tat twam asi) identity, stems from the same original belief that might have convinced Plato of the homogeneity of nature, Newton of the analogy of nature and modern science of the uniformity of nature. In the absence of any empirical proof, they all have been convinced a priori. As a dynamic theory, totalism entails a perennial transformation and recurrence from oneness to multiplicity and from multiplicity to oneness, through a set of four feedback or 'spinback' loops (Fig. 1b).

But no modern school of thought, philosophical or otherwise, deviates from the concession of time as a straight line, nor from the dogma that modernity is totally superior to its past. This rescinds modernity's superiority dogma and connects the hellenic cosmosystem [7] with Plato's favorite topic in his Laws: the equality, justice and liberty triptych. And so does Heidegger, who along with his teacher, Edmund Husserl, influenced Maurice Merleau-Ponty (Fig. 2). Closely linked to Epicurus, Jean-Paul Sartre and Simone de Beauvoir, Merleau-Ponty's is a sustained argument for the foundational role that our human perception plays in understanding our cosmos as well as engaging with our cosmos [23].

The legacy of René Descartes' notorious dualism of body and mind has been so penetrative [4, 9, 27], that most of us tend to treat the mind and its main organ, the brain, as our body's boss, the pilot of the ship, as if it were [10, 11]. "Plato's Theaetetus, Saint Augustine, and Saint Thomas contain most of what is affirmative in the Meditations... Descartes ... brought... very nearly to completion, the dualism of mind and matter which begun with Plato and was developed, largely for religious reasons, by Christian philosophy" [27, p. 567]. Yet, our autonomic nervous system is not a 'mind' at all, but a spinback control system, which Aristotle called the 'vegetative soul'. It preserves a living system's integrity.

In the absence of any dogma or any organized priesthood in hellenic tradition, it was the $\pi \circ \lambda \iota \tau \varepsilon i ́ \alpha$ (politeia) (a)

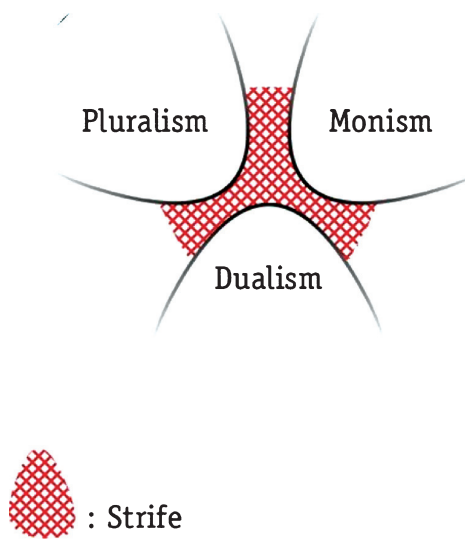

( b )
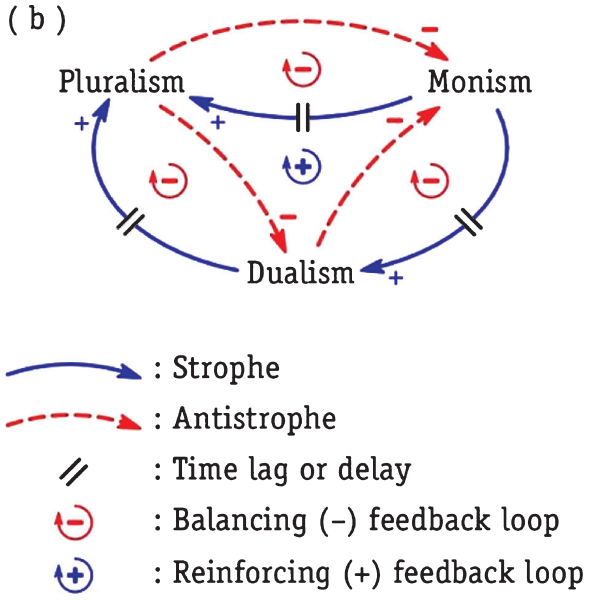

Descartes' mind-body dualism $\neq$ Plato's soul-body dualism

Fig. 1. Reconciling three hellenic-isms: a) static view and b) dynamic-complexity view. 


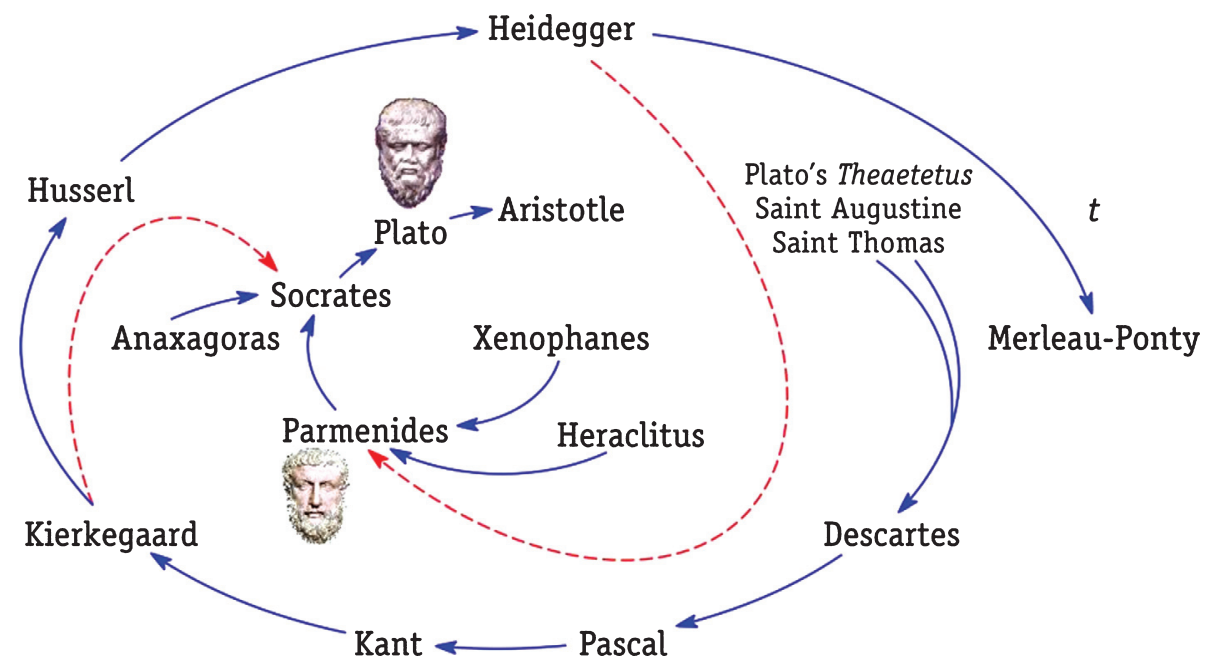

Fig. 2. Philosophical strophe $(\rightarrow)$ and antistrophe $(-->)$ through the time $(t)$ spiral.

itself, i.e., the citizen body or dēmos, which undertook to prosecute and to punish those who were 'impiously disposed' [20]. That was the societal and political backdrop where Plato grew up, settling all questions through reason, thereby interpreting our human comportment in rational terms, and with the belief that $A \rho \varepsilon \tau \dot{\eta}$ or virtue essentially entails rational living. The historical conditioning of his life, i.e., Socrates' trial, might have compelled Plato not to give up rationalism but to extend it metaphysically. Undoubtedly, Socrates' hints must have turn in Plato's mind; simple things, such as, for example: "the human $\psi \nu \chi \eta$ [psyche or soul] has something divine about it" and "one's first interest is to look after its health" [12, p. 209].

Plato crucially identifies a detachable 'occult' self as the carrier of guilt, potentially divine with the rational $\psi v \chi \dot{\eta}$, whose $\alpha \rho \varepsilon \tau \dot{\eta}$ or virtue is $\gamma \nu \omega ́ \sigma \iota \varsigma$, i.e., knowledge. The shamanistic trance, which deliberately detaches the occult self from the body, became a mental withdrawal and concentration to purify the rational soul under the authority of $\lambda o ́ \gamma o \varsigma$. The occult $\gamma \nu \omega ́ \sigma \iota s$ became a $\Theta E A$ (deity or view) of metaphysical $\alpha \lambda \dot{\eta} \theta \varepsilon \iota \alpha$ or truth, just as the $\alpha \lambda \dot{\eta} \theta \varepsilon \iota \alpha$ or recollection of past lives became the $\alpha \lambda \dot{\eta} \theta \varepsilon \iota \alpha$ of bodiless forms, i.e., a new epistemology platform $[12,17]$. While Phaedo shows the

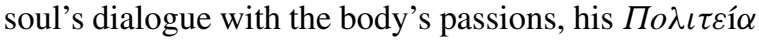
vividly shows an internal dialogue between two parts of the soul, an inner-conflict theory that Plato precisely formulates in the Sophist.

Plato's fission of the person into a $\delta \alpha 1$ í $\mu \omega \nu$ (dæmon) and beast is similar to his human-nature dualism, which corresponds to a wide gulf between human potential: what a person might be, and Plato's estimate of the person as s/he is. So Plato's dualism suggests a religious origin, which one can meet often in later religious thinkers, from the roman emperor Marcus Aurelius to T.S. Eliot, who said in almost the same words: "human nature is able to endure only a very little reality", which agrees with the drift of much else in Plato's Laws [12, p. 215].

In Heidegger's [17] provocative dialogue with the natural and cosmogonic phase of hellenic philosophy, i.e., the 'pre-Socratics', his central theme is the question of $A \lambda \hat{\eta} \theta \varepsilon \iota \alpha$ or truth and its primordial understanding in Parmenides' didactic poem. Heidegger highlights the contrast between hellenic and roman thought and reflects on that contrast in language. Beyond an interpretation of hellenic philosophy, Parmenides offers a strident critique of our modern temporality, delivered during a time that Heidegger sees as 'out of joint'.

Dreyfus [13] sees the way that Blaise Pascal and Søren Aabye Kierkegaard responded to René Descartes as a strain in philosophy. Everybody in the PlatoAristotle Hellenic philosophy tradition had tried to figure out what we essentially are. They thought we were essentially minds. Pascal was the first to say that the human condition is fundamentally contradictory. Kierkegaard sees that the self is a contradiction between the finite and the infinite, the temporal and eternal, the possible and the necessary. But he thought the bodymind distinction is not as useful. To get these seemingly contradictory factors together, Kierkegaard advanced the notion of calling: one is called to have an unconditional commitment or an infinite passion for something. 
Kierkegaard calls it leveled. Heidegger takes that up and calls it being 'authentic'.

A fundamental democracy principle entails binding collective decisions to help people end our modernity's polyarchy [8,32]. Which renders Plato's insight important, not only because of his position in the history of thought, but also because Plato perceived clearly the risk inherent in the decay of an 'inherited conglomerate'. In his final testament to the cosmos, Plato put forward explicit proposals for sustainability through a societal counter-reformation [12, p. 207]. In this context, two questions become pertinent to the situation facing Plato: 1) How much importance did he attach to the irrational aspects of our human comportment and how did he perceive them? 2) How much was he willing to give in to popular belief for the sake of sustaining the inherited conglomerate of his time?

In perfect syzygy with the plural rationality of persons, societal groups and organizations, Singer contrasts monothematic conventional universes of traditional rationality with the 'multiverse-directed' view of 'plural rationality' [28, 29]. In counterpoint, Morecroft's [24] computed scenarios trace the dysfunctional interactions among sales objectives, overtime and salesforce motivation to the intended, i.e., stated, singular rationality that drove action in a large sales organization.

Invariably, within their multiverse-directed plural rationality, all five research contributions in this special issue address politics because politics is the area where the systemic leverage [16] is, if our species is to enjoy collective economic prosperity and societal eudaimonia. With those ends in mind, the section below introduces briefly the harmonious cohabitation of the five research contributions that follow the guest editorial in this HSM Special Issue.

\section{The HSM special issue contributions}

The five research articles of this HSM Special Issue on transformation and societal change research provide a special collection of excellent transdisciplinary research contributions (Table 1). The HSM special issue sets a foundation of the human-systems-management research community, through cross-fertilization among diverse research communities. Their contributions span divergent research areas and thereby provide a rich set of insights across the whole spectrum of transformational and societal change research.

Theology does not seem to be the specialty of any of the contributors here. Yet, one way or another, each one of the special-issue articles seems to address something that has to do with societal religiosity. That could be because societal $\theta \varepsilon \sigma \sigma \varepsilon \varepsilon \varepsilon \varepsilon \iota \alpha$ or reverence for the divine has a much more logical footing than our modernity's financialized zombie economism, which seeks financial stability and sustainability at the expense of instability in and non-sustainability of the real economy of goods and services; at the expense of our collective economic prosperity and societal eudaimonia.

Politics is another common thread. All five articles agree that political system reforms constitute a prerequisite to transformation and societal change.

The article by Christos C. Evangeliou, titled "Socratic lessons in excellence for our postmodern world", sets the tone for the entire HSM Special Issue.

Table 1

The HSM Special Issue contributions to transformation and societal change research

\begin{tabular}{llc}
\hline Contribution & Author(s) & Research themes \\
\hline a & C.C. Evangeliou & excellence, ethics, Hellenic and Indian philosophy, Socrates, Plato \\
K. Hiwaki & entelechy, market fundamentalism, modern civilization, paradigm shift, \\
power structure, relational mutuality, sound diverse cultures, sustainable \\
development, \\
c
\end{tabular}


Socrates' three-dimensional conception of $A \rho \varepsilon \tau \dot{\eta}$ or Arete $(\sim$ virtue) shows it as a general concept, even if the general always presents itself in its limited, situation-specific form. By recasting Socrates beyond the ironist and skilful practitioner of his Socratic method, Evangeliou has Socrates reemerge as something more substantial philosophically: he can inspire others to excellence by following his example of living his simple life and facing his tragic death calmly. From his new analytic of Plato's Apology, Evangeliou draws five distinct lessons for our badly needed transformation and societal change, one of them addressing political leaders as well as all those people who fill political offices too (Table 1a).

Evangeliou's search for societal and political excellence as well as for an antidote to moral relativism and other sorts of sophistry in modernity serves as a preamble to the contribution by Kensei Hiwaki, titled: "Sustainable development requires diverse sound cultures". For Hiwaki complements Socrates well with principles from the Tao tradition. His search of reasonably 'sound cultures' across the world can help perpetually sustain a long-term, futureoriented, sound communal value system that consists of human integrity, solidarity, continuity and mutuality. In response to Fukushima, it is nothing short of a paradigm shift for sustainable development that Hiwaki seeks, as he derives, from his value-real interactions dynamic framework (or clockwork) contribution, an optimal development path (ODP) for our prospective global community's sustainable development (Table 1b).

Next comes the article by Sotirios (Sam) Karras. Titled "Comprehending transformational critical thinking", the article looks at systems functioning in us that cause radical societal change as the products of us - our society's producers and users. At once, Karras makes not one, but two contributions. The first entails the discovery of a largely overlooked, new agent in the systems functioning in us, most pertinent to our transformation problematic. The second contribution entails the disclosure of another new, also overlooked societal agent, which we also produce in our image. This second new societal agent, Karras presents as a solution to our societal change problematic (Table 1c).

Concerned with transformation and societal change in advanced and mature societies, Milan Zeleny's contribution is titled: "Crisis and transformation: on the corso and ricorso of human systems". In lieu of merely reporting on the failing globalization phenomenon, Zeleny sees signs of a reversal toward relocalization, i.e., a rebounding after the strong global outbound of the past fifty years. He is also concerned with both the change of paradigms and the change of dominant business models that accompany such transformations. Yet, transformations get naturally confounded with ongoing recessions and crises. Disentangling the phenomena of crisis from those of transformation remains a challenge, especially for politicians. In his article, Zeleny addresses primarily the issues of unemployment and the changing nature of employment in mature economies, along with technology and high-technology drivers of transformation, democracy being its socio-political prerequisite (Table 1d).

Following Zeleny's lead, in order to help our modern temporality metamorphose for the benefit of all concerned, Nicholas C. Georgantzas and Georges D. Contogeorgis seek systemic leverage in the principles behind Athenians' authentic democracy. Titled: "Societal metamorphosis via authentic democracy principles", their contribution challenges the fraudulent image of what is called 'Western democracy'. No, they are not suggesting that our modernity returns to antiquity, but democracy's multiple equality, liberty and civic-accountability dimension bundles do take their role in a multi-perspective dialectic about their dynamic societal implications. The article's two small system dynamics (SD) models showcase a vexing problem that Athenians' authentic democracy solved rather effectively, that of political corruption. Even though heavily constrained by the familiar, 'social contract' idea, Rawls' [26] solution to the 'distributive justice' problem follows the Aristotelian roots of the Kantian tradition (Fig. 2), and thereby would readily appeal to the benevolent, just, moral and, essentially, commonsense mores of American pragmatism. Rawls' high priority for liberty is in perfect harmony with the 'universal-liberty project' that Georgantzas and Contogeorgis put forth (Table 1e).

\subsection{A future research implications example}

The potential implications for the future research issues raised here on transformation and societal change are not just tremendous but also vastly interrelated. To give but one example of how this is so, while leaving the rest up your own creative imagination, let's consider Karras' contributions first, which seem to emanate from his looking at the human mind is us as an infinitedimensional vector space of all possibilities, which consists of all our emotional, mental and sensory combinations of an infinite ideo-emotional vector basis with complex coefficients. 
We generally trust the human mind in us to make our ethos reasonable, i.e., to structure our human character so that the powers of the human soul, the passions, will be educated to choose actions that promote the common societal good in a unified and intelligent way [3]. So it might need further justification how such a finite organ such as the brain in us, with finite cells, molecules and atoms, can feel a myriad of things, making it seem to have an infinite size. Is it our prior integrated knowledge of the finite, which translates everything, from cognitive, emotional and sensory stimuli, in terms that we can understand an infinite number of non-equivalent ideo-emotional ramifications?

Second, and closely linked to this challenging future research issue comes Zeleny's quest for reintegrating task, labor and education in modernity, so that we no longer speak of "specialization", but of "integrated rather than specialized education, training and skills acquisition." Which is closely related not only to the changing nature of Zeleny's technology-high technology cycle, but also to E $\lambda \lambda \eta \nu \iota \sigma \mu$ ó $\varsigma$ as a program of paideia and pedagogy, the very culture of our society. Given the finite mind in us, with its seemingly infinite processing capacity, our supporting the presence of the classical E $\lambda \lambda \eta \nu \iota \sigma \mu$ ó $\zeta$ in educational programs implies that we seek to counter drastically the rising tide of professionalism of the financialized homo technicus, on the one hand, and to strengthen the humanities, on the other.

The truth is that a university can never function outside our society, which needs members who are at once professionals, scientists and, above all, true citizens. Yet our universities seem to have been skipping their traditional role of providing constructive criticism to our society. It was once one of their fundamental functions to $u n$-conceal for our human society $A \lambda \dot{\eta} \theta \varepsilon \iota \alpha$ ( the truth) about itself. Serving as our society's memory and consciousness, universities were the places from where one could freely criticize society and propose radical changes to it, without fear of recrimination. Academic tenure was created to ensure precisely that academic liberty to criticize and to suggest. Alas, the primary function of tenure today has become to protect the jobs of incompetent specialists.

Receiving the baton in our modernity from the defeated capitalism and the even worse defeated marxism, the new feudalism of financialized zombie economism, i.e., the markets, displace us, humans, at increasingly greater rates, forcing our crowd (forget society) to think incessantly and with an also increasingly personal distress about numbers, interest rates and other financial concerns. The result is a fast-growing financial dependence of both private and public educational institutions on government funding, which renders academics

acutely aware of the principle source of the butter on their bread and, in the case of public institutions, of the bread itself. Academics are not inclined to bite the hand that feeds them and that hand is attached to a mind that wants its behavior rationalized, not criticized [1, p. 228].

\section{Concluding remarks}

Unabating the idea crisscrossed my mind while writing this guest editorial. It had something to do with

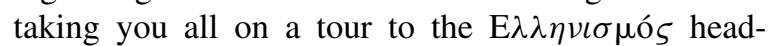
quarters. But I fought the impulse bravely, leaving its majestic plot for a future episode and restricted myself to reconciling three hellenic -isms instead. That section, I am hoping, will come in handy as you read through the philosophy nubs in the five fascinating applied-research contributions that follow.

In addition to the authors of the accepted research articles archived here, many more people contributed to this HSM Special Issue. I thank and apologize to all those contributors whose research got rejected, but am most indebted to Dr. Milan Zeleny, HSM's Editor-inChief, who supported the idea for a special issue on transformation and societal change. Also, I am grateful to all the highly skilled people of IOS Press, Amsterdam, NL, for their accommodating assistance and flexible patience. I sincerely hope that this HSM special issue will serve as a prototype for future $H S M$ special issues, which will further integrate transformation and societal change with social science research and practice.

\subsection{Wrong questions produce no answers}

I am finding Daniel C. Dennett's bumper-sticker definition of philosophy increasingly useful. It looks something like this: 'Philosophy is what you do until you start asking the right questions'. It is useful because the wrong questions invariably produce no answers, just as political polls often reflect our modernity's political crisis. In its esoteric essence, the political crisis merely reflects the failure of political parties to give satisfactory answers or solutions to the problems of society and country. The vicious cycle of our 
political crisis will continue and will deepen as long as our societal and political forces avoid facing the right questions. Missed by the extant societal and political systems in and around which we all live, these questions undermine social cohesion, dissolve the economy and exacerbate vicious circles, which spin perpetually, leaving no outlet for our urgently needed radical transformation and societal change.

To give but one example, as this HSM Special Issue is poised to motivate much useful future research and publications on transformation and societal change, here is a vexing question that concerns us all, our entire human species on the surface of planet Earth. Every business, economic, financial, societal and political organization must ask itself this question frequently, always with an eye toward radical transformation and societal change: ARE WE A MISTAKE OR JUST MISTAKEN?

\section{References}

[1] R.L. Ackoff, The Democratic Corporation: A Radical Prescription for Recreating Corporate America and Rediscovering Success. Oxford University Press: New York, NY 1994.

[2] Anon., Real. German debt may be 7 trillion euros not 2 trillion: Professor, Commodity Online (27 Sep. 2011), available online (27 Nov. 2011): www.commodityonline.com/tags/europeandebt-crisis-mktmovetag.html.

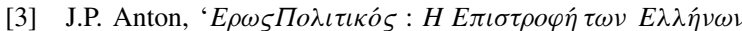
(Political Eros: The Hellenes' Return), Mí $\lambda \eta \tau$ os (Miletus): Athens, Hellas (2010).

[4] S. Broadie, Soul and body in Plato and Descartes, Proceedings of the Aristotelian Society 101(1) (2004), 295-308.

[5] W.E. Buffett, Stop coddling the super-rich, New York Times (15 Aug. 2011), A21.

[6] J. Calmes, Obama tax plan would ask more of millionaires, New York Times (18 Sep. 2011), A1.

[7] G.D. Contogeorgis, The Hellenic Cosmosystem, v.1. The Statocentric Period, I. Sideris: Athens, Hellas (2006).

[8] R.A. Dahl, Polyarchy: Participation and Opposition, Yale University Press, New Haven, CT (1972).

[9] A. Damasio, Descartes' Error: Emotion, Reason and the Human Brain, Avon Books: New York, NY (1994).

[10] D.C. Dennett and Darwin's, "strange inversion of reasoning", Proceedings of the National Academy of Sciences, 106(Supplement 1) (2009), 10061-10065.

[11] D.C. Dennett, Consciousness Explained Little, Brown and Co., Boston, MA (1991).

[12] E.R. Dodds, The Greeks and the Irrational, University of California Press, Berkeley, CA (1951).

[13] H.L. Dreyfus, Being-in-the-World: A Commentary on Heidegger's Being and Time Division I, MIT Press, Cambridge, MA (1991).
[14] S. Faris, Regime change in Europe: do Greece and Italy amount to a bankers' coup?, TIME World (11 Nov. 2011), available online (27 Nov. 2011): www.time.com/time/world/ article/0,8599,2099350,00.html.

[15] T.L. Friedman, Something's happening here, New York Times (12 Oct. 2011), A23.

[16] N.C. Georgantzas and J.L. Ritchie-Dunham, Designing highleverage strategies and tactics, Human Systems Management 22(1) (2003), 1-11.

[17] M. Heidegger, Parmenides (A. Schuwer and R. Rojcewicz transltr.), Indiana University Press, Bloomington, IN (1992).

[18] N.A. Kaloy NA, Totalism or the Will to Happiness, Prolegomena to a General Theory of Philosophy, Fondation Kaloy: Geneva, Switzerland, 2002, available online (27 Nov. 2011): www.nicolaskaloy.com/philo_what_is_totalism.htm.

[19] P. Krugman, Confronting the malefactors, New York Times (7 Oct. 2011), A27.

[20] I. Liritzis and A. Coucouzeli, Ancient Greek heliocentric views hidden from prevailing beliefs? Journal of Astronomical History and Heritage 11 (1), (2008), 39-49.

[21] J. Madison, The Debates in the Federal Convention of 1787 Henry D. Gilpin and the U.S. Library of Congress, Washington, DC (1840).

[22] A. Melissaratos and N.J. Slabbert, Innovation: The Key to Prosperity, Technology and America's Role in the 21st Century Global Economy Montagu House, New York, NY (2009).

[23] M. Merleau-Ponty, Phenomenology of Perception (C. Smith transltr.), Routledge, London, UK (2005).

[24] J.D.W. Morecroft, Rationality in the analysis of behavioral simulation models, Management Science 31 (1985), 900-916.

[25] J. Paxman, Michael Moore: 'Occupy' movement has 'touched a nerve', BBC Newsnight (18 Oct. 2011), available online (27 Nov. 2011): news.bbc.co.uk/2/hi/programmes/newsnight/ 9619110.stm.

[26] J.B. Rawls, A Theory of Justice (revised edition) BelknapHarvard University Press, Cambridge, MA (1999).

[27] B. Russell, A History of Western Philosophy. Simon \& Schuster New York, NY (1972).

[28] A.E. Singer, Strategy as moral philosophy, Strategic Management Journal 15 (1994), 191-213.

[29] A.E. Singer, Strategy as rationality, Human Systems Management 11(1) (1992), 7-21.

[30] Y. Singh, The Coming Europe speech by Joseph Goebbels, (21 Apr. 2008), based on "Das kommende Europa, Rede an die tschechischen Kulturschaffenden und Journalisten," Die Zeit ohne Beispiel, ("The upcoming Europe, Speech to the Czech artists and journalists", The time without precedent), Zentralverlag der NSDAP, Munich, Germany, (1941), pp. 314-323, available online (9 Nov. 2011): www.hitlerblog. com/national-socialism/coming-europe-joseph-goebbels/.

[31] R.D. Wolff, The truth about 'class war' in America, The Guardian (22 Sep. 2011), available online (27 Nov. 2011): www.truth-out.org/class-war-issue/1316617081.

[32] H. Zinn, A People's History of the United States 1492-Present, HarperCollins, New York, NY (1980). 